Dunamis: Jurnal Teologi dan Pendidikan Kristiani

Volume 6, Nomor 1 (Oktober 2021)

ISSN 2541-3937 (print), 2541-3945 (online)

https://www.sttintheos.ac.id/e-journal/index.php/dunamis

DOI: $10.30648 /$ dun.v6i1.581

Submitted: 5 Mei 2021

Accepted: 23 Juni 2021

Published: 31 Oktober 2021

\title{
Efikasi Misa Online sebagai Sakramen Keselamatan pada Masa Pandemi Covid-19: Kritik Naratif Markus 5:25-34
}

\author{
R.F. Bhanu Viktorahadi'; Busro Busro ${ }^{2 *}$ \\ Program Studi Ilmu Filsafat, Fakultas Filsafat, Universitas Katolik Parahyangan Bandung ${ }^{1}$; \\ Jurusan Studi Agama-Agama, Fakultas Ushuluddin, UIN Sunan Gunung Djati Bandung ${ }^{2}$ \\ busro@uinsgd.ac.id
}

\begin{abstract}
The emergency situation due to the Covid-19 pandemic has forced Catholics to worship by attending online mass. Although it is seen as a quick and responsive solution for the Church, many have questioned the efficacy or usefulness of online mass as a means and sign of God's salvation for His people. This paper provides an explanation of the efficacy of online mass as a sacrament of salvation by using the text Mark 5:25-34 about a haemorrhaging woman suffering who received miracles of healing after touching the garment of Jesus. This study was conducted by Narrative Criticism with the Exegetical Symbol Analysis approach. The analogy of the miracle of healing obtained by touching the robe of Jesus provides an understanding that the efficacy of online mass as a sacrament of salvation continues to work even though it is not experienced directly or in distance.
\end{abstract}

Keywords: online mass; sacrament of salvation; narrative criticism; eucharist; covid-19 pandemic

\begin{abstract}
Abstrak
Kondisi darurat akibat pandemi Covid-19 memaksa umat Katolik beribadah dengan mengikuti misa secara online. Walaupun dipandang sebagai solusi cepat dan tanggap Gereja, banyak yang mempertanyakan efikasi atau daya guna misa online sebagai sarana dan tanda keselamatan Tuhan bagi umat-Nya. Tulisan ini memberi penjelasan tentang efikasi misa online sebagai sakramen keselamatan dengan menggunakan teks Markus 5:25-34 tentang perempuan penderita pendarahan yang memeroleh mukjizat penyembuhan setelah menyentuh jubah Yesus. Metode yang digunakan adalah Kritik Naratif dengan pendekatan Eksegese Analisis Simbol. Analogi mukjizat penyembuhan yang diperoleh hanya dengan menjamah jubah Yesus memberikan pemahaman bahwa efikasi misa online sebagai sakramen keselamatan tetap bekerja walaupun tidak dialami secara langsung alias berjarak.
\end{abstract}

Kata Kunci: misa online; sakramen keselamatan; kritik naratif; ekaristi; pandemic covid-19 


\section{PENDAHULUAN}

Sakramen adalah suatu misteri kudus yang sudah ada sejak awal. Sakramen ini memanifestasikan keselamatan. Ungkapan aslinya dalam bahasa Latin adalah " $\mathrm{S} a$ cramentum est res sacra arcana salutaris, salutem manisfestans." Ungkapan ini keluar dari mulut Quintus Septimius Florens Tertullianus atau Tertullianus (155-230) ${ }^{1}$, seorang penulis sekaligus teolog awal Kristen. Hingga kini ungkapannya masih menjadi rujukan, terkait efikasi atau daya guna sakramen dalam Gereja Katolik. Umat Katolik meyakini bahwa dalam sakramen berupa simbol-simbol tertentu, Allah hadir. Saat hadir atau merepresentasikan diri-Nya, Allah merealisasikan keselamatan bagi manusia. Dengan kata lain, sakramen adalah sarana dan tanda keselamatan Allah bagi manusia. ${ }^{2}$ Dalam kondisi normal keyakinan itu dapat terus terjaga. Akan tetapi, saat

\footnotetext{
1 Sakramentologi C. Groenen, "Ciri Sakramental Karya Penyelamatan Allah," in Sejarah, Wujud, Struktur (Yogyakarta: Kanisius, 1989), 54.

2 Adrianus Sunarko, Rahmat dan Sakramen. Berteologi dengan Paradigma Kebebasan. Jilid 2 (Yogyakarta: Penerbit Obor, 2018).

3 Alfons No Embu, "Pengalaman Postreligius Dan Media Sosial Digital Dalam Praktek Misa Online Di Masa Pandemi Covid-19," Jurnal Masalah Pastoral 8, no. 2 (2020): 20-49; Dono Darsono, Jajang A Rohmana, dan Busro Busro, "Against COVID-19 Pandemic: Bibliometric Assessment of World Scholars' International Publications related to COVID-19," Jurnal Komunikasi Ikatan Sarjana Komunikasi Indonesia 5, no. 1 (Juni 2020), https://doi.org/10.25008/jkiski.v5i1.356; Samuel Benyamin Hakh, "Perjamuan Kudus Virtual di Rumah Anggota Jemaat: Analisis Alkitabiah tentang Kehadiran Allah berdasarkan Yohanes 4:21-24," DUNAMIS: Jurnal Teologi dan Pendidikan
}

kondisi abnormal, apakah keyakinan itu masih tetap bertahan?

Setahun terakhir dunia terkena wabah Pandemi Covid-19 (Corona Virus Disease 2019). Virus yang pertama muncul dari kota Wuhan, Cina pada akhir 2019 tersebut menyebar ke berbagai negara di dunia, termasuk Indonesia. ${ }^{3}$ Penyebaran virus Covid19 yang cepat dan luas ini telah mengubah banyak aspek hidup manusia, termasuk liturgi atau tata peribadatan sakramen Gereja Katolik. ${ }^{4}$ Berdasarkan anjuran pemerintah Republik Indonesia untuk menjaga jarak sosial (social distancing), jaga jarak fisik (physical distancing), dan sementara waktu di rumah saja, ${ }^{5}$ para Uskup di Indonesia yang tergabung dalam Konferensi Waligereja Indonesia (KWI) menerbitkan instruksi dan surat edaran di masing-masing wilayahnya untuk mengakomodasi anjuran tersebut. ${ }^{6}$ Salah satu wujud akomodasi itu

Kristiani 5, no. 2 (April 2021): 460-80, https:// doi.org/10.30648/dun.v5i2.524.

${ }^{4}$ Mario Tomi Subardjo, "Kebaruan Liturgi di Masa Pandemi Covid-19," Utusan, 2020; R F Bhanu Viktorahadi, "Perubahan Pola Sakramen Umat Katolik Bandung Pada Era Pandemi Covid-19," TEMALI: Jurnal Pembangunan Sosial 4, no. 1 (2021): 72-79, https://doi.org/10.15575/jt.v4i1. 12310; Hasse Jubba, "Beradaptasi dengan Bencana: Strategi Beribadah Umat Islam dan Kristen di Tengah Pandemi Covid-19," Religious: Jurnal Studi Agama-Agama dan Lintas Budaya 5, no. 1 (2021): $1-14$.

${ }^{5}$ Muhammad Radityo Priyasmoro, "Pemerintah: di Rumah Saja untuk Kendalikan Corona dan Antisipasi Demam Berdarah," Liputan 6 (Jakarta, 2020).

${ }^{6}$ Nur Habibie, "KWI: Ada Tantangan Spiritual Saat Beribadah dari Rumah di Tengah Wabah Coro," Liputan 6, 2020. 
adalah Perayaan Sakramen Ekaristi atau Misa online.

Pertanyaan pada paragraf pertama kembali bergaung. Apakah keyakinan bahwa sakramen, termasuk Sakramen Ekaristi adalah sarana dan tanda keselamatan dari Allah untuk manusia masih dapat dipertahankan? Pertanyaan ini terutama bergaung di antara umat atau jemaat yang merasakan dan mengalami langsung misa online. Bagi beberapa dari mereka, misa semacam ini tidak menghadirkan perjumpaan dan pengalaman langsung. Akibatnya, efikasi atau daya guna misa online sebagai sakramen yang membawa dan menghadirkan keselamatan pun kurang atau bahkan tidak dialami. Pertanyaan itu sekaligus menjadi permasalahan pertama penelitian ini, yaitu apakah sakaramen online sah sebagai sarana dan tanda keselamatan?

Guna menjawab permasalahan itu penelitian ini menggunakan narasi mukjizat penyembuhan perempuan yang dua belas tahun mengalami pendarahan (Mrk. 5:2534) untuk menjawabnya dari sudut pandang tafsir teks Kitab Suci. Dengan menggunakan metode tafsir naratif, penelitian ini mengajukan permasalahan kedua, yaitu bagaimana narasi itu dapat membantu memberikan deskripsi bahwa sakramen masih diya-

7 Ruth O Oke, "Healing of the Haemorrhaging Woman as a Model for Checkmating Stigma ff People Living with HIV," Verbum et Ecclesia 38, no. 1 (2017): 1-12. kini sebagai sarana dan tanda keselamatan. Untuk membantu terbangunnya deskripsi itu, analisis dan tafsiran terhadap narasi tersebut akan mendapat bantuan dari narasi yang paralel dari dua Injil Sinoptik lainnya, yaitu Injil menurut Matius (Mat. 9:20-22) dan Injil menurut Lukas (Luk. 8:43-48).

Sejumlah penelitian dengan ranah serupa telah terlaksana. Antara lain, penelitian yang dilakukan Thomas Onggo Sumaryanto dan Hariawan Adji serta R.O. Oke. ${ }^{7}$ Thomas Onggo Sumaryanto dan Hariawan $\mathrm{Adji}^{8}$ mengemukakan bahwa gereja perlu membantu umat untuk merefleksikan atau merenungkan lebih mendalam lagi relasi Tuhan dan manusia dalam cyberspace. Oleh karena itu, gereja memiliki tugas berat setelah pandemi Covid-19 ini berakhir. Sedangkan R.O. Oke memberi pemaparan tentang identitas perempuan yang menderita pendarahan dua belas tahun. Menurut Oke, kondisi perempuan yang menderita, termarginalisasi, dan penuh kecemasan inilah yang justru menumbuhkan harapan dan keberaniannya untuk berinisiatif mengambil tindakan iman menyentuh (jumbai) jubah Yesus sehingga memeroleh mukjizat kesembuhan. Penelitian ini secara khusus mempertemukan kedua penelitian terdahulu tersebut dalam suatu tujuan, yaitu memberi-

\footnotetext{
${ }^{8}$ Thomas Onggo Sumaryanto dan Hariawan Adji, "Persekutuan Umat Allah di Dalam Cyberspace," Jurnal Teologi Kontekstual Indonesia 1, no. 2 (2021): 127-42.
} 
kan pemahaman tentang efikasi misa online sebagai sakramen keselamatan pada masa pandemi Covid-19. Titik temu ini sekaligus menjadi kebaruan (novelty) dari penelitian ini.

\section{METODE PENELITIAN}

Guna memahami narasi mukjizat penyembuhan perempuan yang dua belas tahun mengalami pendarahan dari teks Markus 5:25-34. Penelitian ini menggunakan Metode Kritik Naratif. Metode Kritik Naratif adalah salah satu sejumlah metode untuk menafsirkan teks kitab suci, karena sebenarnya teks kitab suci dapat dianalisis dari aneka macam sudut pandang dan dipelajari dengan berbagai metode. ${ }^{9}$

Supaya dapat mengikuti cara kerja metode ini, terlebih dahulu perlu konseptualisasi atas istilah yang digunakan dalam nomenklaturnya. Istilah "metode" bermakna serangkaian prosedur yang membuka akses lebih objektif pada subjek penelitian. Sedangkan istilah "kritik naratif" bermakna bahwa teks kitab suci senantiasa memiliki ketergantungan pada dinamika naratif yang juga mengikutsertakan realitas ekstra-tekstual (sejarah, politik, dan sosial-kemasyarakatan $)^{10}$ penafsir dan pembacanya. Dengan

9 J. Severino Croatto, Biblical Hermeneutics: Towards a Theory of Reading as the Production of Meaning (Maryknoll: Orbis Books, 1987), 10.

10 Horacio Simian-Yofre, "Diacronia: I Metodi Storico-Critici," in Horacio Simian-Yofre, Metodologia dell'Antico Testamento (Bologna: Edizioni Dehoniane Bologna, 2002), 79-80. demikian, Metode Kritik naratif adalah suatu metode untuk memahami dan mengkomunikasikan pesan-pesan Kitab Suci yang selaras dengan wujud narasi dan kesaksian personal, yang merupakan karakter dari kitab suci dan sekaligus suatu model fundamental dari komunikasi antar-manusia. ${ }^{11}$

Metode Kritik Naratif banyak digunakan untuk menafsirkan teks-teks kitab suci. Alasannya, hampir sepertiga kitab suci terdiri atas teks-teks narasi karena pada dasarnya pewartaan iman kristiani adalah rangkaian pengajaran atau katekese yang berwujud narasi. ${ }^{12}$ Metode Kritik Naratif bekerja dengan memahami dan mengkomunikasikan pesan-pesan yang muncul dari teks kitab suci berwujud narasi. Narasi itu memuat karakter, plot (alur), latar belakang kisah, dan dinamika komunikasi, termasuk simbol-simbol yang digunakan untuk berkomunikasi. Interaksi dalam komunikasi antar-tokoh dalam narasi ini merupakan salah satu ciri khas teks kitab suci. ${ }^{13}$ Sebagai salah satu dari banyak metode yang digunakan dalam penelitian tafsir teks kitab suci, Metode Kritik Naratif masuk dalam kategori analisis literal yang meneliti teks kitab suci menurut aspek-aspek kesusastraan. ${ }^{14}$

\footnotetext{
${ }^{11}$ Komisi Kitab Suci Kepausan, Penafsiran Alkitab dalam Gereja (Yogyakarta: Kanisius, 2003), 57.

12 Shimon Bar-Efrat, Narrative Art of Bible (Sheffield: Sheffield Academic Press, 1997), 9.

${ }^{13}$ Komisi Kitab Suci Kepausan, Penafsiran Alkitab dalam Gereja, 57.

${ }^{14}$ A.A. Sitompul dan U. Beyer, Metode Penafsiran Alkitab (Jakarta, 1973), 50.
} 
Metode Kritik Naratif meletakkan narasi sebagai cermin yang memantulkan atau merefleksikan makna bagi penafsir atau pembacanya untuk hidup aktualnya. Dengan sudut pandang ini, Metode Kritik Naratif menjadi cara tepat untuk membuat penafsiran teks kitab suci kontesktual dengan kondisi dunia dan cara pandang ilmiah pada saat itu. ${ }^{15}$ Pilihan menggunakan Metode Kritik Naratif pada penelitian ini mendapat dukungan dari kenyataan bahwa subjek penelitian ini adalah teks kitab suci dengan genre narasi dari Perjanjian Baru.

Oleh karena unsur-unsur dari narasi Injil menurut Markus memuat sejumlah simbol, penelitian ini juga menggunakan pendekatan Eksegese Analisis Simbol untuk menarik makna dari simbol-simbol yang muncul. Penggunaan pendekatan Eksegese Analisis Simbol (Analisi EsegeticoSimbolica) dalam penelitian ini beralasan. Alasannya, narasi yang menjadi subjek penafsiran memuat sejumlah unsur berupa simbol. Tafsiran atas simbol-simbol itu akan membantu membangun tafsiran yang lebih rinci. Menurut L. Gasparro ${ }^{16}$, untuk menarik makna dari semua kekayaan teks, terutama narasi, seorang penafsir tidak dapat berhenti pada karakteristik sederhana

\footnotetext{
${ }^{15}$ Martin Volkmann, Método Histórico-Crítico (São Paulo: CEDI, 1992), 26-27.

${ }^{16}$ L. Gasparro, Simbolo e narrazione in Marco. La dimensione simbolica del secondo Vangelo alla luce
}

dari simbol yang muncul dari narasi itu. Proses terpenting dari upaya menafsir adalah perkembangan dan kontribusi khusus dari simbol-simbol itu pada narasi. Sebuah simbol dalam narasi tidak dapat diperlakukan secara terpisah karena kemunculannya seiring dengan simbol yang lain. Selain itu, simbol juga memiliki kapasitas untuk membangkitkan realitas, gagasan, atau tema yang sangat luas.

Metode Kritik Naratif membantu pembaca dan penafsir memahami dan mengkomunikasikan pesan teks kitab suci sesuai dengan wujud naratif yang ada. Teks yang berwujud narasi memiliki unsur-unsur khasnya, yaitu alur (plot), latar belakang (setting), dan penokohan (karakter). Pada gilirannya unsur-unsur tersebut mengikat pembaca dan penafsir ke dalam dunia naratifnya dan sekaligus sistem nilai yang termuat di dalamnya.

Menurut Marguerat dan Bourquin, plot adalah kesatuan struktur yang menghubungkan aneka peristiwa dalam narasi sekaligus menatanya ke dalam satu kesatuan naratif. Tujuannya, menarik minat pembaca dan memberi pengaruh emosional kepadanya. ${ }^{17}$ Sedangkan menurut M.A. Powell, latar belakang (setting) adalah suatu fungsi

della pericope del fico di Mc 11,12-25. (Roma: Gregorian Biblical Press, 2012), 50-58.

${ }^{17}$ Daniel Marguerat dan Yvan Borquin, How to Read Bible Stories: An Introduction to Narrative Criticism (London: SCM Press, 1999), ix. 
yang memberikan informasi terkait kapan, di mana, dan bagaimana suatu narasi dikisahkan. ${ }^{18}$ Selanjutnya, karakter adalah tokoh-tokoh yang berperan dalam narasi. Tokoh-tokoh tersebut membuka peluang bagi pembaca dan penafsir untuk diinterpretasikan sebagai pribadi dengan kualitas moral, intelektual, dan emosi tertentu. Interpretasi atas pribadi itu ditarik dari alur pengisahan (plot) atau melalui kata-kata maupun tindakan-tindakan si tokoh. ${ }^{19}$ Dalam hal ini karakter tidak dapat memisahkan diri dari plot. Plot bagaikan kerangka payung (gagang dan jari-jarinya). Sedangkan karakter adalah daunnya. ${ }^{20}$

Tanpa mengesampingkan pentingnya latar belakang, berdasarkan keterkaitan antara plot dan karakter inilah teks Markus 5:25-34 akan mengalami analisis, terutama analisis atas tokoh perempuan yang dua belas tahun mengalami pendarahan dan mendapatkan kesembuhan.

18 M.A. Powell, What is Narrative Criticism (Minneapolis: Fortress Press, 1990), 69.

${ }^{19}$ Powell, 52.

20 Marguerat dan Borquin, How to Read Bible Stories: An Introduction to Narrative Criticism, 58.

21 J.S. Pobee, "HIV/AIDS in Africa: A Biblical Perspective," in Globalization, Technology, HIV/AIDS and Theological Education in Africa, ed. oleh D. Ayegboyin, H. Agbanu, dan E. Nihinlola (Ibadan: WAATI, 2010), 80-95.

22 A.O. Okunlola, "Menstrual Blood and Priestly Roles," in African Women and the Quest for Women's Right, ed. oleh D.O. Akintunde (Ibadan: Sefer Books, 2001), 27-35.

\section{HASIL DAN PEMBAHASAN}

\section{Kondisi Perempuan}

J.S. Pobee menyatakan bahwa narasi perempuan yang dua belas tahun menderita pendarahan menurut teks Markus 5:2534 ini adalah kisah tentang penderitaan, rasa sakit, dan penyakit tak tersembuhkan yang mengeksploitasi semua sisi perasaan sedih dan emosional si sakit. ${ }^{21}$ Narasi bungkam terkait identifikasi jenis penyakitnya. Narasi hanya menyebut pendarahan yang diderita si perempuan itu sebagai penyakit yang tidak tersembuhkan. Kemungkinan besar itu terjadi akibat belum adanya teknologi medis pada saat itu yang sanggup mengatasinya. ${ }^{22}$ Penyakit itu berfungsi hanya untuk mengidentifikasi si perempuan. ${ }^{23}$ Tanpa penyakit, si perempuan nyaris tidak memiliki identitas apa pun. Ia anonim. ${ }^{24}$ Dengan kata lain, sudah sejak awal narasi menempatkan perempuan ini sebagai sosok marginal dan berjarak dari rahmat Allah. ${ }^{25}$ Kondisi sakit si perempuan ini mengindikasikan sekurang-kurangnya dua hal. Pertama, pe-

23 Priscille Djomhoue, "Gender and Ethics in the Fight Against HIV/AIDS: A Case Study of Mark 5: 25-34 in an African Context," in Into the Sunshine: Integrating HIV/AIDS into Ethics Cuirriculum, 2005, 131.

${ }^{24}$ Juan Mateos e Fernando Camacho dan Il Vangelo di Marco, "Analisi linguistica e com-mento esegetico," in Lettura del Nuovo Testamento 1 (Assisi: Cittadella, 1997), 461.

${ }^{25}$ Hisako Kinukawa, Women and Jesus in Mark: A Japanese Feminist Perspective (Oregon: Wipf and Stock Publishers, 2003). 
rempuan ini mengalami pendarahan selama dua belas tahun berturut-turut tanpa henti. Oleh karena itu, secara fisik ia pasti sangat lemah tersebab kekurangan darah dalam tubuh. Kedua, akibat pendarahannya itu ia masuk kategori orang marginal atau bahkan buangan. ${ }^{26}$ Kedua hal itu menunjukkan bahwa si perempuan mengalami dua penderitaan, yaitu fisik dan mental.

Penderitaan mental jauh lebih berat. Penderitaan mental ini mencakup penderitaan secara psikologis, sosial, dan ritual. Ia terpaksa mengalami dua belas tahun dalam kesia-siaan. Selama waktu itu sang perempuan harus hidup terpisah secara menyakitkan. Ia mendapat pengucilan dari masyarakat, bahkan keluarganya. Ia mendapat perlakuan seperti orang buangan yang najis dan berdosa. ${ }^{27}$ Dalam tradisi Yahudi, seorang perempuan dengan aliran darah yang berkepanjangan mendapat sanksi sosialritual dalam wujud pengasingan dari masyarakatnya dan keharusan mengenakan pakaian kabung dari karung. Setiap kali keluar dari pengasingannya ia harus berteriak “"najis" pada dirinya sendiri. Selama periode pengasingan itu sang perempuan menja-

\footnotetext{
${ }^{26}$ Oke, "Healing of the Haemorrhaging Woman as A Model For Checkmating Stigma of People Living with HIV."

27 C.E.W. Dorris, A Commentary on the Gospel According to Mark (Nashville: Gospel Advocacy, 1975), 127.

${ }^{28}$ F. Belo, A Materialistic Reading of the Gospel of Mark (New York: Orbis Book, 1981), 41-44.

29 D. Guthrie dan J.A. Motyer, The New Bible Commentary (London: IVP, 1970), 154.
}

di sesuatu yang tidak boleh kena sentuh. ${ }^{28}$ Setelah aliran darah itu berhenti, perempuan itu masih harus menjalani masa observasi selama tujuh hari untuk memverifikasi kesembuhannya. Selanjutnya, imam harus mempersembahkan korban penebusan baginya sebelum ia dapat kembali berintegrasi dengan masyarakat dan ikut serta dalam ibadat. $^{29}$

Bagi sang perempuan, pendarahan selama dua belas tahun itu menjadi wabah yang menjauhkan dirinya dari rasa nyaman secara fisik sekaligus dari masyarakat, keluarga, dan ritual. Walaupun tidak ada alasan khusus untuk mencurahkan perhatian pada angka dua belas sebagai suatu simbol yang perlu ditafsirkan, ${ }^{30}$ sejumlah ahli berpendapat bahwa jangka waktu dua belas tahun sebenarnya bermakna simbolis. Pertama, dua belas tahun menunjukkan penderitaan yang sangat panjang. Dengan kata lain, penderitaan perempuan itu sangatlah berat dan lama. ${ }^{31}$ Kedua, jangka waktu itu berfungsi menghubungkan kedua tokoh dalam narasi yang tersusun secara bertumpuk (sandwich). ${ }^{32}$ Yang dimaksud dengan struktur sandwich adalah pola naratif yang

\footnotetext{
${ }^{30}$ Mark R.H. Stein, Baker Exegetical Commentary on the New Testament (Grand Rapids: Baker Academic, 2008), 267.

${ }^{31}$ Ben Witherington, The Gospel of Mark: A SocioRhetorical commentary (Michigan: Wm. B. Eerdmans Publishing, 2001).

${ }^{32}$ Marcin Moj, "Sandwich Technique in the Gospel of Mark," The Biblical Annals 8, no. 65/3 (2018): 363-77.
} 
menggunakan dua narasi dengan yang memiliki kemiripan alur, tetapi dengan tokoh, alur, dan latar belakang yang berbeda. Struktur ini membantu pembaca dan penafsir untuk menemukan pusat perhatian atau pesan narasi, yaitu tema yang sama. Dalam teks Markus, kedua narasi itu memiliki pusat perhatian yang sama, yaitu mukjizat yang dilakukan Yesus dalam wujud penyembuhan terhadap dua perempuan yang berbeda. Inti pesannya adalah mukjizat penyembuhan. ${ }^{33}$ Ketiga, jangka waktu itu bermakna politis-keselamatan. ${ }^{34}$ Angka dua belas mengingatkan jumlah orang-orang terpilih, baik dalam tradisi Perjanjian Lama (suku-suku Israel) maupun dalam tradisi Perjanjian Baru (para rasul). ${ }^{35}$ Dengan kata lain, kedua perempuan (anak perempuan Yairus dan perempuan yang dua belas tahun mengalami pendarahan) yang menderita itu pun adalah orang-orang terpilih. ${ }^{36}$

\section{Menjamah Jubah Yesus}

Perempuan itu datang kepada Yesus sebagai upaya terakhir setelah semua upaya

\footnotetext{
33 Mateusz Kusio, "Theological Implications of Markan Interpretative Intercalations," Ruch Biblijny i Liturgiczny 68, no. 3 (2015): 265-88.

${ }^{34}$ Musa W Dube, "Talitha cum! Calling the GirlChild and Women to Life in the HIV/Aids and Globalization Era," in African Women, HIV/AIDS and Faith Communities (Cluster Pietermaritzburg, 2003), 71-93.

35 J. Dewey, "The Gospel of Mark, Searching the Scriptures," in A Feminist Commentary, ed. oleh E.S. Fiorenza (New York: Crossroad, 1994), 470509.

${ }^{36}$ M. Girard, Symboles bibliques, langage universel: pour une théologie des deux Testaments ancrée dans
}

duniawi dicobanya. ${ }^{37}$ Penginjil Markus mengungkapkannya secara jelas, "Ia telah berulang-ulang diobati oleh berbagai tabib, sehingga telah dihabiskannya semua yang ada padanya, namun sama sekali tidak ada faedahnya malah sebaliknya keadaannya makin memburuk" (Mrk. 5:26). Oleh karena itu, tindakan perempuan saat maju mendekati Yesus dari belakang dan menjamah jumbai jubah-Nya merupakan perbuatan yang masuk akal sebagai wujud usahanya meraih kesembuhan. ${ }^{38}$ Alasannya, ia sudah mendengar berita-berita tentang Yesus (Mrk. 5:27a). Akan tetapi, tindakan perempuan itu bukan tanpa rintangan. Rintangan pertama yang menghadangnya adalah dari dalam dirinya sendiri atau rintangan internal. Walaupun mengetahui bahwa Yesus dapat menyembuhkannya, perempuan itu merasa takut. Ketakutannya itu muncul sebagai akibat dari rasa ketidaklayakan dirinya. ${ }^{39}$ Ketidaklayakan ini tersebab struktur sosial kemasyarakat pada waktu itu menghukumnya dengan pengucilan. ${ }^{40}$ Dengan menggunakan narasi penyembuhan perem-

\footnotetext{
les sciences humaines (Montréal: Médiaspaul, 2016), 1071-85.

37 W. Barclay, The Gospel of Mark: Daily Bible series (Edinburgh: The Saint Andrew Press, 1981), 130.

38 Vernon K Robbins, "The woman who touched Jesus' garment: Socio-rhetorical analysis of the synoptic accounts," New Testament Studies 33, no. 4 (1987): 502-15.

39 R. Frew, Notes on New Testament Explanatory and Practical (Grand Rapids, MI: Baker Books, 1949), 349.

${ }^{40}$ R.N. Brock, Journey to Heart: A Christology of Erotic Power (New York: Crossroad, 1988), 83.
} 
puan itu Penginjil Markus bermaksud menyampaikan bahwa kekuatan atau kualitas iman sanggup mengatasi ketakutan akibat tahyul atau ketakutan yang muncul secara psikologis. $^{41}$

Terlepasnya perempuan dari rintangan internal itu membuahkan hasil positif. Perempuan itu berhasil keluar dari dirinya sendiri untuk menyentuh Yesus. Narasi menyebut bahwa akibat sentuhan si perempuan, suatu kekuatan yang bahkan tidak dapat ditahan Yesus supaya tidak keluar dari diriNya. Gagasan bahwa kekuatan semacam itu dapat disedot dari seorang suci dikenal sudah sejak lama. ${ }^{42}$ Gagasan semacam itu dapat saja menyeret orang untuk membayangkan kekuatan magis yang dimiliki seseorang dengan kekuatan yang luar biasa atau supranatural seperti dalam mitologi Yunani kuno. ${ }^{43}$ Akan tetapi, narasi ini istimewa. Keistimewaannya terletak dari ungkapan bahwa tenaga itu keluar hanya dengan sentuhan terhadap jubah Yesus. Bahkan, narasi dari Penginjil Matius (Mat. 8:44) dan Penginjil Lukas (Luk. 9:21) secara lebih spesifik menyebut bahwa perempuan itu tidak hanya ingin menyentuh jubah Yesus, tetapi secara lebih khusus jumbai jubah-Nya.

\footnotetext{
${ }^{41}$ Mary Rose D'Angelo, “Gender and Power in the Gospel of Mark: The Daughter of Jairus and the Woman with the Flow of Blood," in Miracles in Jewish and Christian Antiquity: Imagining Truth, ed. oleh John C. Cavadini (Notre Dame: University of Notre Press, 1999), 83-109.

42 Joel Marcus, Mark 1-8. A New Translation with Introduction and Commentary (New York: Doubleday, 2000).
}

Perempuan itu melakukan tindakan sembunyi-sembunyi itu dengan merangkak. Posisi merangkak itu menyiratkan ketakutan dan kerendah-hatian, sekaligus penyerahan diri dan permohonan. ${ }^{44}$ Ia menyebut bahwa tindakan perempuan itu menjadi penggenapan atas nubuat Zakaria. 45 "Pada waktu itu sepuluh orang dari berbagai-bagai bangsa dan bahasa akan memegang kuatkuat punca jubah seorang Yahudi dengan berkata: Kami mau pergi menyertai kamu, sebab kami dengar, bahwa Allah menyertai kamu!" (Zak. 8:23).

Tindakan perempuan itu menyentuh jumbai jubah sebagai bagian terluar dari tubuh dan pakaian menjadi upaya terselubung atau tersembunyi untuk mendapatkan kontak dengan Yesus. Jumbai jubah adalah bagian terluar dari tubuh, bahkan pakaian orang dalam tradisi Yahudi. Jumbai jubah yang panjang bahkan dapat terseret dan menyentuh tanah saat orang yang mengenakannya berjalan. Dengan kata lain, jumbai jubah itu sejajar posisinya dengan kaki yang terkena pasir, tanah, bahkan kotoran. ${ }^{46}$ Akan tetapi, walaupun posisinya adalah bagian terluar, jumbai jubah, sebagaimana ka-

\footnotetext{
${ }^{43}$ Hervé Savon, "Wendy Cotter, Miracles in GraecoRoman Antiquity. A Sourcebook," L'Antiquité Classique 70, no. 1 (2001): 338-39.

44 Joseph Fitzmyer, The Gospel According to Mark (New York: Doubleday, 1985), 742-247.

${ }^{45}$ Fitzmyer Dame, 742-47.

46 Siegmar Schulter-Gallera dan Fusz-und SchuhSymbolik und Erotik, Folkoristische und sexualwissenschaftliche Untersuchungen (Darmstadt: Bläschke, 1909), 21.
} 
ki juga tetap menjadi bagian tidak terpisahkan dari orang yang menggunakannya. Selain itu, sebagai bagian terluar sekaligus paling bawah, sebagaimana kaki, jumbai jubah menjadi semacam kontak si pengguna jubah (pakaian) dengan tanah atau bumi tempat berpijak. Jumbai jubah itu menjadi semacam penghubung antara keprihatinan yang terjadi di bumi dengan permohonan yang disampaikan si pengguna jubah itu kepada Allah yang senantiasa dibayangkan berada di sorga (atas). ${ }^{47}$

Saat perempuan itu menyentuh (jumbai) jubah-Nya, Yesus berseru. "Siapa yang menjamah jubah-Ku?" (Mrk. 5:30b).

Seruan ini menjadi bukti bahwa ada relasi integral antara Yesus dengan pakaian dalam wujud (jumbai) jubah-Nya. ${ }^{48}$ Dengan kata lain, menyentuh (jumbai) jubah Yesus sama dengan menyentuh-Nya. Sebagai bandingan, sejumlah narasi dalam Perjanjian Baru juga menyebut adanya kekuatan yang keluar saat seseorang menyentuh pakaian. Ada narasi tentang orang di Efesus yang membawa saputangan atau kain yang pernah dipakai Paulus dan meletakkannya atas orang-orang sakit, maka lenyaplah penyakit

\footnotetext{
${ }^{47}$ Barbara Baert dan Emma Sidgwick, "Touching the Hem: The Thread between Garment and Blood in the Story of the Woman with the Haemorrhage (Mark 5: 24b-34parr)," Textile 9, no. 3 (2011): 308-51.

${ }^{48}$ B. Baert, "The Woman with the Blood Flow," in Narrative, Iconic, and Anthropological Spaces, ed. oleh B. Baert (Leuven - Walpole, MA: Peeters, 2014), 51-80; L.G. Tack, Cleansed in the Wine of the Passion. On the Role of Jesus' Garment in the
}

mereka dan keluarlah roh-roh jahat (Kis. 19:12). ${ }^{49}$ Sementara itu Perjanjian Lama juga menunjukkan adanya ekstensifikasi diri seseorang melalui pakaian yang digunakannya dalam jubah Elia. ${ }^{50}$ Teks 2 Raja-raja 2:13-16 mengisahkan bahwa Elisa memungut jubah Elia yang telah terjatuh. Selanjutnya, Elisa berjalan hendak pulang dan berdiri di tepi sungai Yordan. Saat rombongan nabi yang dari Yerikho melihat Elisa dari jauh mereka pun berseru, "Roh Elia telah hinggap pada Elisa” (2 Raj. 2:15a).

Pada akhir tindakan penyembuhan Yesus menyampaikan pernyataan khusus kepada sang perempuan, "Hai anak-Ku, imanmu telah menyelamatkan engkau" (Mrk. 5:34b). Pernyataan Yesus ini sama sekali bukan termasuk pernyataan untuk tindakan penyembuhan. Sebaliknya, pernyataan itu mengungkapkan kualitas sang perempuan. Perempuan itu menyadari sepenuhnya tindakannya mencari kesembuhan. Ia juga mengetahui dan menyadari bahwa dirinya telah mendapat kesembuhan yang diharapkannya. Sekarang, ia mendapat affirmasi bahwa alasan kesembuhan yang diperolehnya adalah berkat iman yang dimi-

Story of the Haemorrhaging Woman (Leuven: Peeters Publishers, 2013).

${ }^{49}$ Pieter J Lalleman, "Healing by a Mere Touch as a Christian Concept," Tyndale Bulletin 48, no. 2 (1997): 355-62.

${ }^{50}$ Douglas R. Edwards, "Dress and Ornamentation," in The Anchor Bible Dictionary, ed. oleh D.N. Freedman (New York: Doubleday, 1992), 235. 
likinya. Narasi secara jelas melukiskan bahwa iman perempuan itu bukanlah sekadar kata benda. Iman yang dimilikinya adalah suatu proses atau dinamika dirinya yang total. Perempuan itu memulai proses berimannya dengan menaruh harapan. Untuk mengungkapkan harapan itu ia masih terhalang ketakutan. Akan tetapi, ia memberanikan diri untuk bertindak. Tindakannya tetap tidak dapat terlepas dari ketakutan. Wujudnya adalah tersungkur dan gemetar. Tindakan ini mengungkapkan kasihnya kepada Yesus dalam wujud rasa hormat. Rasa hormat itu mendatangkan keselamatan baginya.

Mukjizat penyembuhan yang dilakukan Yesus pada kedua perempuan tidak hanya melepaskan mereka dari bahaya sakit dan maut. Mukjizat itu juga memulihkan kemampuan mereka untuk melahirkan kehidupan baru. Berkat mukjizat penyembuhan itu keduanya kini dapat melahirkan kehidupan baru dari tubuh mereka. ${ }^{51}$ Gadis anak Yairus dapat menjadi perempuan yang sesungguhnya dengan melahirkan. Sedangkan, sang perempuan yang tadinya sakit dapat memulihkan predikatnya sebagai perempuan sejati. ${ }^{52}$ Dengan kata lain, mereka pulih sebagai seorang perempuan sekaligus

\footnotetext{
${ }^{51}$ D.J. Harrington dan Sacra Pagina, The Gospel of Mark (Collegeville, MN.: The Liturgical Press, 2002), 174.

52 Brock, Journey to Heart: A Christology of Erotic Power.
}

berpotensi melahirkan kehidupan yang sempurna. Intervensi Ilahi dalam diri Yesus membongkar blokade situasi kemandulan yang tadinya seakan-akan permanen menjadi situasi subur dalam wujud kemungkinan lahirnya hidup baru dari kedua perempuan itu. ${ }^{53}$

\section{Keselamatan Sakramental (Berjarak)}

Keseluruhan dinamika proses beriman sang perempuan menjadi nilai positif dirinya. Dengan mengungkapkan nilai-nilai positif dirinya, sang perempuan dapat melihat dan mengalami nilai-nilai positif yang dimiliki Yesus. Dengan demikian, saat kesembuhan itu terjadi posisi keduanya menjadi seimbang. Oleh karena itu, Yesus memberikan salam sekaligus berkat yang umum diberikan dalam tradisi Yahudi saat kedua belah pihak memiliki posisi yang seimbang, "Pergilah dengan selamat" (Mrk. 5:34c). Salam atau berkat standar Yahudi itu dapat dijumpai juga dalam teks-teks Hakim-hakim 18:6; 1 Samuel 1:17; 2 Samuel 15:9. Selanjutnya Yesus menambahkan satu pernyataan lain, "sembuhlah dari penyakitmu!" (Mrk. 5:34d). Pernyataan ini seakan-akan melemahkan mukjizat penyembuhan yang telah terjadi, karena seakan-akan si perempuan itu belum benar-

\footnotetext{
53 B. Standaert, "Évangile selon Marc. Commentaire," in Première partie (Pendé: Gabalda, 2010), 401.
} 
benar sembuh. ${ }^{54}$ Oleh karena itu, sejumlah ahli menyarankan pembacaan alternatif. Misalnya, "jaga dirimu supaya tetap sehat." Pernyataan semacam itu biasa diungkapan mereka yang berlatar budaya Yunani. ${ }^{55}$ Lepas dari itu, dengan memberikan berkat standar secara tradisi Yahudi dan menambahkan pernyataan berikutnya yang datang dari budaya Yunani, Yesus telah menggabungkan dua tradisi besar. Hasilnya, mukjizat penyembuhan ini sebenarnya tidak hanya dapat diperoleh mereka yang berasal dari tradisi Yahudi, tetapi juga yang datang dari tradisi Yunani atau lainnya. Dengan kata lain, mukjizat penyembuhan Yesus ini bersifat universal.

Secara analogis, mukjizat penyembuhan perempuan itu dapat menjadi manifestasi mukjizat keluaran bangsa Israel (exodus) saat menyeberangi Laut Teberau (Kel. 14:15-31). ${ }^{56}$ Tindakan menyentuh jumbai jubah Yesus itu menjadi tindakan simbolik sang perempuan dalam melakukan kontak batin dengan Yesus sebagai suatu peziarahan menuju keselamatan. Narasi mukjizat penyembuhan ini mencerminkan

\footnotetext{
${ }^{54}$ Gerd Theissen, The Miracle Stories of the Early Christian Tradition (Edinburgh: T. \& T. Clark, 1983), 176.

55 B.P. Grenfell dan A.S. Hunt, The Oxyhrynchus Papyri IV (London: Egypt Exploration Fund, 1904), 743.43; 745.10; 746.9-10; 805.

${ }^{56}$ Elizabeth Struthers Malbon, "The Jesus of Mark and the Sea of Galilee," Journal of Biblical Literature 103, no. 3 (1984): 363-77.

${ }^{57}$ Elizabeth A Livingstone, Studia Biblica 1978. III: Papers on Paul and Other New Testament Authors,
}

pembebasan melalui air menuju hidup baru yang menyelamatkan. Dengan kata lain, narasi ini menyarankan suatu analogi sakramen baptis dan ekaristi dalam konteks paskah. ${ }^{57}$ Kontak yang muncul dari sikap rendah hati dan kepasrahan ini mendapat ungkapan sakramentalnya dalam ritus-ritus zona perbatasan dan transit. Dalam hal ini yang dimaksud dengan ritus-ritus zona perbatasan dan transit adalah Tuhan Kasihanilah (kyrie), kemuliaan, doa-doa presidensial, dan doa-doa permohonan. Ritus-ritus itu mengungkapkan sikap rendah hati, suka cita, sekaligus penyerahan diri kepada kehendak Allah yang dilandasi dengan iman. ${ }^{58}$

Perempuan yang sakit pendarahan selama dua belas tahun memeroleh rahmat kesembuhan karena menjamah (jumbai) jubah Yesus. Dengan kata lain, ia mendapatkan keselamatan padahal tidak menyentuh Yesus secara langsung, tetapi hanya menyentuh (jumbai) jubah-Nya. Menjadi jelas bahwa sakramen Allah paling jelas dan sempurna bagi manusia adalah Yesus Kristus sendiri. ${ }^{59}$ Hal ini juga ditegaskan

vol. 3 (London: Bloomsbury Publishing, 1980); John T. Cummings, "The Tassel of His Cloak: Mark, Luke, Matthew and Zechariah," Studia Biblica 2 (1980): 47-61.

${ }^{58}$ H-F IMBERT, "Claude Gandelman, Le Regard dans le texte. Image et écriture du Quattrocento au XXe siècle (Book Review)," Revue de Littérature Comparée 65, no. 3 (1991): 362.

${ }^{59}$ F.-J. Nocke, "Allgemeine Sakramentenlehre," in Handbuch der Dogmatik 2, ed. oleh T. Schneider (Düsseldorf: Patmos Verlag, 2000), 188-225. 
Ambrosius ( \pm 340-397) saat menjelaskan rahmat keselamatan dalam Sakramen Baptis yang diperoleh berkat percikan air baptis. Jadi hendaklah engkau percaya di sana (dalam air) ada kehadiran Allah. Ungkapan aslinya dalam bahasa Latin adalah 'crede ergo divinitatis illic (in aquis) adesse prosentiam.' Seandainya ada rahmat keselamatan dalam air itu, rahmat keselamatan itu datang bukan dari air itu sendiri, melainkan dari kehadiran Yesus. ${ }^{60}$

\section{KESIMPULAN}

Dengan menganilisis dan menemukan pesan dari narasi mukjizat penyembuhan yang dilakukan Yesus terhadap perempuan yang dua belas tahun mengalami pendarahan, pertanyaan terkait legalitas misa online pada masa pandemi Covid-19 menemukan jawabannya. Narasi mengungkapkan bahwa perempuan itu tidak dapat secara langsung menyentuh Yesus. Ia mengalami jarak. Akan tetapi, jarak itu tidak menghalanginya memeroleh mukjizat karena ia telah berhasil mengatasi jarak itu dengan iman. Iman perempuan itu meyakinkan dirinya bahwa walaupun hanya jumbai jubah yang berhasil disentuhnya, ia tetap berjumpa dan mengalami Yesus sendiri. Analogi itu berlaku pada misa online. Dalam situasi darurat, misa online tetap sah karena yang menjadi sumbernya tetaplah Yesus sendiri. Supaya daya guna atau efikasinya penuh, umat harus memiliki iman kuat sekaligus keterbukaan untuk memberi ruang pada rahmat ilahi yang bekerja.

\section{UCAPAN TERIMA KASIH}

Penulis mengucapkan terima kasih kepada Fakultas Filsafat, Universitas Katolik Parahyangan Bandung dan Fakultas Ushuluddin UIN Sunan Gunung Djati Bandung yang telah mendukung penelitian ini.

\section{DAFTAR PUSTAKA}

Baert, B. "The Woman with the Blood Flow." In Narrative, Iconic, and Anthropological Spaces, diedit oleh B. Baert, 51-80. Leuven - Walpole, MA: Peeters, 2014.

Baert, Barbara, dan Emma Sidgwick. "Touching the Hem: The Thread between Garment and Blood in the Story of the Woman with the Haemorrhage (Mark 5: 24b-34parr)." Textile 9, no. 3 (2011): 308-51.

Bar-Efrat, Shimon. Narrative Art of Bible. Sheffield: Sheffield Academic Press, 1997.

Barclay, W. The Gospel of Mark: Daily Bible series. Edinburgh: The Saint Andrew Press, 1981.

Belo, F. A Materialistic Reading of the Gospel of Mark. New York: Orbis Book, 1981.

Brock, R.N. Journey to Heart: A Christology of Erotic Power. New York: Crossroad, 1988.

60 C. Groenen, "Ciri Sakramental Karya Penyelamatan Allah.” 
C. Groenen, Sakramentologi. "Ciri Sakramental Karya Penyelamatan Allah.” In Sejarah, Wujud, Struktur. Yogyakarta: Kanisius, 1989.

Camacho, Juan Mateos e Fernando, dan Il Vangelo di Marco. "Analisi linguistica e com-mento esegetico." In Lettura del Nuovo Testamento 1. Assisi: Cittadella, 1997.

Croatto, J. Severino. Biblical Hermeneutics: Towards A Theory of Reading as the Production of Meaning. Maryknoll: Orbis Books, 1987.

Cummings, John T. "The Tassel of His Cloak: Mark, Luke, Matthew and Zechariah." Studia Biblica 2 (1980): 47-61.

D’Angelo, Mary Rose. “Gender and Power in the Gospel of Mark: The Daughter of Jairus and the Woman with the Flow of Blood." In Miracles in Jewish and Christian Antiquity: Imagining Truth, diedit oleh John C. Cavadini, 83-109. Notre Dame: University of Notre Dame Press, 1999.

Darsono, Dono, Jajang A Rohmana, dan Busro Busro. "Against COVID-19 Pandemic: Bibliometric Assessment of World Scholars' International Publications related to COVID-19." Jurnal Komunikasi Ikatan Sarjana Komunikasi Indonesia 5, no. 1 (Juni 2020).

https://doi.org/10.25008/jkiski.v5i1.3 56.

Dewey, J. "The Gospel of Mark, Searching the Scriptures." In A Feminist Commentary, diedit oleh E.S. Fiorenza. New York: Crossroad, 1994.

Djomhoue, Priscille. "Gender and Ethics in the Fight Against HIV/AIDS: A Case Study of Mark 5: 25-34 in an African Context." In Into the Sunshine: Integrating HIV/AIDS into Ethics Cuirriculum, 2005.
Dorris, C.E.W. A Commentary on the Gospel According to Mark. Nashville: Gospel Advocacy, 1975.

Dube, Musa W. "Talitha cum! Calling the Girl-Child and Women to Life in the HIV/Aids and Globalization Era." In African women, HIV/AIDS and faith communities, 71-93. Cluster Pietermaritzburg, 2003.

Edwards, Douglas R. "Dress and Ornamentation." In The Anchor Bible Dictionary, diedit oleh D.N. Freedman. New York: Doubleday, 1992.

Embu, Alfons No. "Pengalaman Postreligius Dan Media Sosial Digital Dalam Praktek Misa Online Di Masa Pandemi Covid-19." Jurnal Masalah Pastoral 8, no. 2 (2020): 20-49.

Fitzmyer, Joseph. The Gospel According to Mark. New York: Doubleday, 1985.

Frew, R. Notes on New Testament Explanatory and Practical. Grand Rapids, MI: Baker Books, 1949.

Gasparro, L. Simbolo e narrazione in Marco. La dimensione simbolica del secondo Vangelo alla luce della pericope del fico di Mc 11,12-25. Roma: Gregorian Biblical Press, 2012.

Girard, M. Symboles bibliques, langage universel: pour une théologie des deux Testaments ancrée dans les sciences humaines. Montréal: Médiaspaul, 2016.

Grenfell, B.P., dan A.S. Hunt. The Oxyhrynchus Papyri IV. London: Egypt Exploration Fund, 1904.

Guthrie, D., dan J.A. Motyer. The New Bible Commentary. London: IVP, 1970.

Habibie, Nur. "KWI: Ada Tantangan Spiritual Saat Beribadah dari Rumah di Tengah Wabah Coro." Liputan 6, 2020. 
Hakh, Samuel Benyamin. "Perjamuan Kudus Virtual di Rumah Anggota Jemaat: Analisis Alkitabiah tentang Kehadiran Allah berdasarkan Yohanes 4:21-24." DUNAMIS: Jurnal Teologi dan Pendidikan Kristiani 5, no. 2 (April 2021): 460-80. https://doi.org/10.30648/dun.v5i2.524

Harrington, D.J., dan Sacra Pagina. The Gospel of Mark. Collegeville, MN.: The Liturgical Press, 2002.

IMBERT, H-F. "Claude Gandelman, Le Regard dans le texte. Image et écriture du Quattrocento au XXe siècle (Book Review)." Revue de Littérature Comparée 65, no. 3 (1991): 362.

Jubba, Hasse. "Beradaptasi dengan Bencana: Strategi Beribadah Umat Islam dan Kristen di Tengah Pandemi Covid-19." Religious: Jurnal Studi Agama-Agama dan Lintas Budaya 5, no. 1 (2021): 1-14.

Kinukawa, Hisako. Women and Jesus in Mark: A Japanese Feminist Perspective. Oregon: Wipf and Stock Publishers, 2003.

Komisi Kitab Suci Kepausan. Penafsiran Alkitab dalam Gereja. Yogyakarta: Kanisius, 2003.

Kusio, Mateusz. "Theological Implications of Markan Interpretative Intercalations." Ruch Biblijny $i$ Liturgiczny 68, no. 3 (2015): 265-88.

Lalleman, Pieter J. "Healing by a Mere Touch as A Christian Concept." Tyndale Bulletin 48, no. 2 (1997): 355-62.

Livingstone, Elizabeth A. Studia Biblica 1978. III: Papers on Paul and Other New Testament Authors. Vol. 3. London: Bloomsbury Publishing, 1980.

Malbon, Elizabeth Struthers. "The Jesus of Mark and the Sea of Galilee." Journal of Biblical Literature 103, no. 3 (1984): 363-77.

Marcus, Joel. Mark 1-8. A New Translation with Introduction and Commentary. New York: Doubleday, 2000.

Marguerat, Daniel, dan Yvan Borquin. How to Read Bible Stories: An Introduction to Narrative Criticism. London: SCM Press, 1999.

Moj, Marcin. "Sandwich Technique in the Gospel of Mark." The Biblical Annals 8, no. 65/3 (2018): 363-77.

Nocke, F.-J. "Allgemeine Sakramentenlehre." In Handbuch der Dogmatik 2, diedit oleh T. Schneider. Düsseldorf: Patmos Verlag, 2000.

Oke, Ruth O. "Healing of the Haemorrhaging Woman as a Model for Checkmating Stigma of People Living with HIV." Verbum et Ecclesia 38 , no. 1 (2017): 1-12.

Okunlola, A.O. "Menstrual Blood and Priestly Roles." In African Women and the Quest for Women's Right, diedit oleh D.O. Akintunde, 27-35. Ibadan: Sefer Books, 2001.

Pobee, J.S. "HIV/AIDS in Africa: A Biblical Perspective." In Globalization, Technology, HIV/AIDS and Theological Education in Africa, diedit oleh D. Ayegboyin, H. Agbanu, dan E. Nihinlola, 80-95. Ibadan: WAATI, 2010.

Powell, M.A. What is Narrative Criticism. Minneapolis: Fortress Press, 1990.

Priyasmoro, Muhammad Radityo. "Pemerintah: di Rumah Saja untuk Kendalikan Corona dan Antisipasi Demam Berdarah.” Liputan 6. Jakarta, 2020.

R.H. Stein, Mark. Baker Exegetical Commentary on the New Testament. Grand Rapids: Baker Academic, 2008. 
Robbins, Vernon K. "The Woman Who Touched Jesus' Garment: SocioRhetorical Analysis of The Synoptic Accounts." New Testament Studies 33, no. 4 (1987): 502-15.

Savon, Hervé. "Wendy Cotter, Miracles in Graeco-Roman Antiquity. A Sourcebook." L'Antiquité Classique 70, no. 1 (2001): 338-39.

Schulter-Gallera, Siegmar, dan Fusz-und Schuh-Symbolik und Erotik. Folkoristische und sexualwissenschaftliche

Untersuchungen.

Darmstadt: Bläschke, 1909.

Simian-Yofre, Horacio. "Diacronia: I Metodi Storico-Critici." In Horacio Simian-Yofre, Metodologia dell'Antico Testamento, 79-80. Bologna: Edizioni Dehoniane Bologna, 2002.

Sitompul, A.A., dan U. Beyer. Metode Penafsiran Alkitab. Jakarta, 1973.

Standaert, B. "Évangile Selon Marc. Commentaire." In Première partie. Pendé: Gabalda, 2010.

Subardjo, Mario Tomi. "Kebaruan Liturgi di Masa Pandemi Covid-19." Utusan, 2020.
Sumaryanto, Thomas Onggo, dan Hariawan Adji. "Persekutuan Umat Allah di Dalam Cyberspace." Jurnal Teologi Kontekstual Indonesia 1, no. 2 (2021): 127-42.

Sunarko, Adrianus. Rahmat dan Sakramen. Berteologi dengan Paradigma Kebebasan. Jilid 2. Yogyakarta: Penerbit Obor, 2018.

Tack, L.G. Cleansed in the Wine of the Passion. On the Role of Jesus' Garment in the Story of the Haemorrhaging Woman. Leuven: Peeters Publishers, 2013.

Theissen, Gerd. The Miracle Stories of the Early Christian Tradition. Edinburgh: T. \& T. Clark, 1983.

Viktorahadi, R F Bhanu. "Perubahan Pola Sakramen Umat Katolik Bandung Pada Era Pandemi Covid-19." TEMALI: Jurnal Pembangunan Sosial 4, no. 1 (2021): 72-79. https:// doi.org/10.15575/jt.v4i1.12310.

Volkmann, Martin. Método HistóricoCrítico. São Paulo: CEDI, 1992.

Witherington, Ben. The Gospel of Mark: A Socio-Rhetorical commentary. Michigan: Wm. B. Eerdmans Publishing, 2001. 